\title{
A Bibliographic Survey on State-Minority Contestations in Post-Colonial Sri Lanka
}

\author{
M. M. Fazil ${ }^{1}$ \\ ${ }^{1}$ Department of Political Science, South Eastern University of Sri Lanka, University Park, Oluvil, Sri Lanka \\ Correspondence: M. M. Fazil, Department of Political Science, South Eastern University of Sri Lanka, University \\ Park, Oluvil, \#32360, Sri Lanka. E-mail: fazrasm@seu.ac.lk
}

Received: November 2, 2018

doi:10.5539/jpl.v12n1p48
Accepted: December 30, $2018 \quad$ Online Published: February 28, 2019

URL: https://doi.org/10.5539/jpl.v12n1p48

\begin{abstract}
There is an extensive body of literature that delves deeply into the question of how a state is constituted, by examining it from various theoretical and empirical perspectives. Scholars engaged in the field of political science, as well as in other fields such as the social sciences, are constantly endeavouring to explain the myriad ways in which states are formed in different regions of the world. According to one set of academics, the social setup that prevailed in most of the post-colonial states of Asia, Africa, and Latin America was mainly due to the plurality of their multi-ethnic, multi-linguistic, and multi-cultural populations. This plurality had a profound effect on the way the state was formed. A significant volume of literature on Sri Lanka too is available, much of which approaches the question of state formation and reconstitution from the standpoint of ethnicity and nationalism. This survey reviews both the theoretical and empirical literature on state constitution/ formation and pays special attention to three main themes; viz. theories on state constitution (formation), research on post-colonial state formation, and studies about Sri Lankan politics. The state-in-society theory is studied with focus on the crucial question of how state and society transform and constitute one another. This is a qualitative study based on text analysis. A wide selection of existing literature was reviewed. This survey shows that there is a paucity of research work on post-colonial state formation in Sri Lanka and state-minority contestations. It also draws attention to the research gaps in existing literature and the need to explore them further.
\end{abstract}

Keywords: post-colonial state formation, Sri Lankan politics, state constitution

\section{Introduction}

An extensive literature delves into how a state is constituted, employing various theoretical perspectives, including conventional (Weber, 1964; Gramsci, 1971; Almond \& Verba, 1963; Skocpol, 1979), culturalist (Archer, 1985; Laitin, 1986), system-dominant structuralist (Geerts, 1973; Nordinger, 1981; Krasner, 1984), and rationalist (Bates, 1981, 1989). All theories dealing with the state greatly emphasize either state autonomy or social autonomy and thus are characterized as bipolar. The Weberian state-society literature on the 1970s and the 1980s is developed as a reaction to both structural-functional and Marxist assumptions, providing support for previous approaches of bringing the state back in. However, the most recent state-oriented literature, which constitutes a subset of works by many Weberian scholars of the 1970s and 1980s, has gone beyond its statist claims. A prominent example is the works of Peter Evans, Dietrich Reuschmeyer, and Theda Skocpol (1985) (eds., Bringing the State Back In. Cambridge: Cambridge University Press). State theorists correctly emphasize that states are constant and direct agents of socioeconomic change, and this observation is especially true in the twentieth century. Migdal demonstrates that "these important assertions have helped sustain the case for bringing the state back in."

Migdal strongly emphasises that the twenty-first-century state is buffeted by the winds of globalisation, namely, supranational entities. Divisive ethnic conflicts must also be stripped off of its myths of unity and omnipotence. In the contemporary world, individuals live in a number of crucial social formation - nations, states, ethnic and other subnational groups, civil society, and the global economy. All these social formations establish authority or at least attempt making powerful demands on the behaviour and psyche of people (Migdal, 2001a). In some instances, a minority considered as a segment of society, challenges the state and attempt to transform and reconstitute the state.

In this regard, Migdal's work "State-in-Society: Studying How States and Society Transform and Constitute One Another" (New York: Cambridge University Press, 2001a) promulgates a view to the effect that state and society 
can constitute each other. Migdal introduces a new concept, i.e., state-in-society approach, which explores the principle of how state and society can establish an inter-dependent relationship as opposed to the conventional views of setting the state and society against each other. With this work, Migdal is instrumental in introducing a concept whereby a mutually transformative nature of relationship between the state and society can emerge. This approach envisaged by Migdal's work can be considered as a point of departure in that it differs from the conventional approaches to state and state constitution (formation).

States may help mould, but they are also continually moulded by, the societies within which they are embedded. Thus, once the state's importance has been emphasised, the intellectual attention immediately shifts to issues of why states do what they do, under what circumstances states are effective, and why states defer in their respective roles and effectiveness (Migdal, 1994, p. 2). Sequentially, these issues cannot be discussed satisfactorily without looking at society, at the state, and society transforming and constituting one another. How does state-in-society offer a scope to study how state and society transform and constitute one another? In the modern world, understanding the term "society" is impossible without the state. The formation of the state has created and activated society. Migdal (1994, p. 23) points out that "interaction of state and society are mutually transforming." The result of the engagement and disengagement of states and social forces are tangible, even momentous; however, outcomes rarely reflects the aims and wills embedded in one another. The clash of social forces, including the state, is mediated through the struggles and accommodations in society's numerous arenas. He explains state and society relations as well as mutual engagement. Special focus is given to struggles and accommodation from the aspects of different components.

When Migdal (1994, p. 20) explains society, he prioritises social forces representing society and interacting with the state on behalf of society. Authoritative and autonomous forces in a society shaped the state in as much or more than it shaped them. Social forces in society represent a powerful mechanism for associative behaviour. These forces encompass informal organisations (e.g., Senegal's patron-client networks or friendship groups and old-boy networks in other societies) and formal organisations (e.g., businesses and churches). They can also be social movements, including those held together by common, strongly motivating sets of ideas (even where obvious organisational ties are absent) (Migdal, 1994, 2001a, 2001b, 2004).

Haddad (2010, p. 1003) argues that the state-in-society approach was first developed to help explain politics in the developing world. Sri Lanka is one of the developing countries selected for study of how a state is constituted, including how state and society attempt to establish mutual transformation. However, Migdal's state-in-society approach is insufficient to examine all aspects of the state and minority contestation; thus, a gap of the state-in-society approach is discussed towards the end of this chapter, including a full explanation of the approach, examining the theoretical and conceptual framework of the study. Below are a few empirical examples capturing mixed results, including the diversity of the complications involved and the complexities encountered in state formation from different parts of the world, a reality reflected in Sri Lanka's state formation.

\section{Post-Colonial State Formation}

Scholarships in the discipline of political science, as well as other fields in the social sciences are, attempt to explain state formations in different regions of the world. Kohli and Shue (1994) point out that "our current approaches to the study of political and social change in developing countries have been profoundly influenced by antecedent intellectual debates concerning the process of modernisation in Europe" (1994, p. 295). Marx, Durkheim, and Weber dominated the nineteenth-century study of social structural transformation in Western Europe. After World War II, most former European colonies became sovereign state (Kohli \& Shue, 1994).

State formation in post-colonial societies differentiated significantly from the formation of the Western capitalist state. Alavi (1972) demonstrates that "on the historical specificity of post-colonial societies, specificity arises from structural changes brought about by the colonial experience." A common significance of the post-colonial state is the retention of the unitary colonial state structure by its ruling classes. Despite drawing attention to South Asia (a continent where the modern state emerged under the influence of European colonisation), Bose (2004) points to a number of cases highlighting the nonlinear processes leading to state formation, even within the same continent (as cited in Shyamika, 2013, p. 1). In addition, Bose and Jalal (2004, p. 95) find that although India, Pakistan, and Sri Lanka were formerly under the British imperial power, they show different patterns of political development and state building shaped by uniquely local circumstances.

Political scientists Crawford Young $(1994,2013)$ and Jeffery Herbst $(2000$, p. 11) both draw attention to post-colonial state formation and authoritarianism in Africa, through the historical perspective of their multiple research publications. They review the political science literature on such important issues in post-colonial African states as the legacy of colonialism and role of local elites, the reasons why African states turned autocratic soon 
after independence. Pade (2010) argues that "the failure of the majority of states in Africa represents a classic example of how European colonisation fostered and exploited ethnicity in Africa with dire consequences for state formation."

Research on Latin American history describes the importance of colonial legacy in its post-colonial state formation and future of the Americans (Alva, 1995 as cited in Berger, 2000). Closely related to debates regarding colonialism have been the emergence of new approaches to post-colonial state formation (Nugent, 1993; Nugent, 1994). Amin-Kahan suggests that the post-colonial state formation process in Latin America differed from Asia and Africa (2012). Scholars "emphasised the vigorous and political change debates over the colonial legacy, state formation and nation-making, elite power, and subaltern accommodation and resistance that cut across the wider study of Latin American History" (Berger, 2000, p. 166).

\subsection{Post-Colonial State Formation and Ethnic Politics}

Another set of the academic literature considers that social set up of most post-colonial states in Asia, Africa, and Latin America formed with plurality involving multi-ethnic, multi-linguistic, and multi-cultures. Weiner (1987) points out that the pattern in most post-colonial countries has been for a single ethnic group to take control of the state. State building/formation frequently tends to curtail the power and prestige of many minority ethnic groups. To the contrary, Horowitz (1989) observes that many emergent regimes appear to have found it convenient to persist with colonial divide-and-rule policies by disproportionately recruiting from specific ethnic communities the cadres for armies, civil policing, the judiciary, and civil service. Thus, seeing the expansion of the state in terms of a neutral process that merely creates institutions for the monitoring of civil society is difficult.

In addition, in instances where mono-ethnic situations prevail, hegemonic groups with large majorities have evidently succeeded in retaining their dominance through the selective use of state power. Moreover, Brown, Collins \& Duguid (1989) observes that nation-building in the post-colonial period may reinforce the relationship between the dominant group and that of state nationalism, where symbols of the former are frequently used as the basis for creating an over-riding national identity.

Thus, even as the ethnic consciousness of the dominant community in such situation is revitalised and finally converted into state nationalism, that of minority groups may conversely perhaps be reshaped and distorted because they are required to either assimilate into the majority group or accept a secondary position as cultural inferiors. In many situations, such pressure from the centre precipitates fissiparous tendencies among regional and ethnic minority groups. Alternately, persistent socioeconomic disadvantages may make lesser social groups susceptible to attract extra-parliamentary forms of dissents. In turn, this phenomenon may generate increased authoritarian responses by the centre to restore social order.

\section{Literature on Sri Lanka}

Significant social science literature in Sri Lanka has also produced an expanding body of analysis on the question of state formation and reconstitution from the standpoint of ethnicity and nationalism. The majority of these writings concentrated on the period after the 1983 pogrom against Tamils, which was instrumental in the escalation of the three-decade civil war. By contrast, the literature reviewed here encompasses the following various themes: colonial legacy, social and ethnic bases, constitutional legacy, institutional decay in governance, majoritarian nationalism, recent radical movements, and the LTTE's state-building process as a strong social force. In addition, the post-war literature on state reconstitution has been reviewed under the following themes: Post-war peace building, state building, nation building, institution building, consequences of victory, ethnic reconciliation, as well as political reform and consolidation of state power. A dominant concern emerging in a number of these studies is the apparent emphasis and priority accorded to the post-colonial state reconstitution project. To fill this gap, this section reviews extensive literature in the field of state reconstitution, under the above-mentioned themes.

Leitan (1990) proves that similar to most third-world countries which emerged from colonialism, Sri Lanka inherited her share of the colonial legacy. Leitan (1990), Uyangoda (2005) as well as Bastian $(2009 ; 2013)$ argue that post-colonial unitary state formation in Sri Lanka was a creation of British colonial rule, a highly centralised political structure both politically and administratively. They further emphasise that this was a reproduction of the constitutional principle of the European/British unitary model. Reconstituting the state has been a recurrent theme in Sri Lanka's political debate since independence in 1948. This reconstitution began in 1949-1950 when a case was made by Tamil minority leaders who favoured amending the constitution of Sri Lanka to offer regional autonomy to their county in the island's Northern and Eastern Provinces (Kearny, 1967; Wilson, 1988, 2000, as cited in Uyangoda, 2013b, p. 1). The federal demand envisaged a structural reconstitution of the post-colonial Sri Lankan state, with two territorial units. Such a vision was a fairly radical demand from the perspective of state formation. The federal demand sequentially generated a counter-argument for a unitary and centralised state. 
As the literature shows, the federal-unitary debate (which became too impassioned and intense in the 1950s and afterwards) failed to gain the same degree of intensity or relevance during the colonial period. This limitation occurred despite occasional arguments for federalism, first by S.W.R.D. Bandaranayake in 1926, then by the Kandyan National Congress in 1929, and Leonard Woolf in 1936. The ethnic minority demand during the late colonial period focused on representation in the colonial legislature and not on state reconstitution. The political debates happening in response to the Soulbury Commission in the mid-1940 indicates that no major disputes occurred on the unitary state model (Marcelline \& Uyangoda, 2013).

Scholars focus much on the social and ethnic bases of the Sri Lankan state and the reconstitution-resistant nature of the country, namely, the Sinhala political elites (Stokke \& Uyangoda, 2011; Uyangoda, 2010b). For example, Bastian (2013, p. 192) points out that "the central feature of the special relationship has preferred the Sinhalese peasantry by the Sinhalese ruling elites as the most crucial social constituency in state policy, policy discourse, state investment and electoral focus." This process results in a centralised state and the ruling class's inability to respond to the political demand of the Tamils.

Coomaraswamy (1996) focuses on the debate of constitutions of Sri Lanka from the state reform and reconstitution aspects. In "Constitution and Constitutional Reform," Coomaraswamy (1993b) surveys Sri Lanka's constitutional history since independence and then critically examines the 1972 and 1978 constitutions and the constitutional reform initiatives between 1987 and 1991. The author identifies the absence of constitutional consensus as a major issue in Sri Lanka. Marcelline (2014) reviews Coomaraswamy's (1996b) work and writes about the constitutional legacy of Sri Lanka as being similar to the centralising tendencies of the Westminster and Gaullist systems. Moreover, she highlights that from 1987 to 1993, the essay covers two themes in Sri Lanka's state reform debate, namely, (a) democracy constitutionalism and rights, and (b) devolution. Similarly, Uyangoda (2013b) interviews in the 1971-1972 period, when the United Front (UF) government embarked on altering the entire constitutional foundation of the Sri Lankan state. Although the UF government reformed the state within a republican model, this particular reform measure had two aspects which went against the pluralistic possibilities of state reconstitution. The first was the reaffirmation in the constitution itself of the unitary and centralised nature of the Sri Lankan state. The second was the total rejection by the UF regime of the Federal Party's argument to incorporate in the new constitution a framework of regional autonomy for minorities. In 1978, the state reconstitution attempt failed and subsequently led to the Jayawardena government's introduction of the French model of a presidential system, which led to a more centralised strong state.

Shyamika (2013) claims that since the late 1980s, scholars from Europe and the United States focused on the Sri Lankan state building/reform/reconstitution. "The structural-policy-issue orientation of European scholarship from this period took a keen interest in Sri Lanka's constitution, institutions and markets (Ludden, 2001, p. 27), slowly causing the demise of the subaltern approach. Also, a large portion of research funding on the state in Sri Lanka since this time has come from the West. As a result, local scholarships have been trapped in criteria set by Western funding agencies, whose primary focus is on elite-oriented approaches to the study of the state." Scholars also note how Sri Lanka has experienced a process of institutional decay in governance (Moore, 1990, 1992; De Votta, 2000, 2004; Bastian, 2011) in the context of economic liberalisation, ethnic conflict, and political violence. De Votta (2004) provides extra attention to ethnic conflict and party system in Sri Lanka, identifying them as creating obstacles to any projects concerned with power sharing. He mainly discusses linguistic nationalism, ethnic outbidding, institutional decay, and Tamil mobilisation in the post-colonial Sri Lanka.

Other scholars (e.g., Thambiah, 1986; Loganathan, 1996; Tiruchelvam, 2000; Jeganathan and Ismail, 1995; Robert, $2001 \mathrm{a} \& \mathrm{~b}$ ) examine how majoritarian nationalism played a major role in avoiding post-colonial state reconstitution in Sri Lanka. In "The Politics of Federalism and Diversity in Sri Lanka," Tiruchelvam (2000) points out that since independence and particularly in the context of the ethnic conflict, federal as well as quasi-federal solutions have been proposed, disputed, and frequently rejected in Sri Lanka's political debates on state reform. The introduction of devolution in 1987 marked a turning point in this debate. This chapter examines the strengths and weaknesses of this system of devolution against the backdrop of the ideological contestation of the nature of Sri Lanka's post-colonial state. The assessment first discusses the ideology of the centralised state and ethnic consciousness, and then followed up with an overview of the system of devolution through the provincial council established in 1987. The third sub-theme concerns the judiciary, pluralism, and the adjudication of disputes relating to devolution. The chapter also provides a review of the draft constitutional proposal of 1996, suggesting that they constituted a "paradigm shift" by moving away from the unitary state model.

Robert (2001a, 2001b) traced Sinhala nationalism and obstacles for power-sharing in "Primordialist Strands in Contemporary Sinhala Nationalism in Sri Lanka: Urumaya as Ur" and in "Burden of History: Obstacles to Power Sharing in Sri Lanka." The Sinhalese nationalist argument for a unitary state is frequently justified by invoking the 
history as found in Sinhalese and Buddhist chronicles. In both these essays, the author critically examines the ideology of the Jathika Hela Urumaya (JHU), a Sinhalese nationalist party strongly opposed to state reform for power-sharing and uses myths and episodes from history to construct a vision for a unitary and centralised state. JHU has been in the forefront of campaigns against any devolution and for the defence of the unitary state. The JHU's ideological and political influences have been significant in the mobilisation of Sinhalese nationalist opinion against a negotiated settlement with the LTTE and power-sharing with ethnic minorities. These two essays deal with a number of inter-connected themes, such as the invocation of historical myths in constructing an argument for a Sinhalese-dominant unitary state, the discursive reconstruction of Sinhalese nationalist ideology by the JHU, and the social and intellectual bases of the key individuals associated with the JHU. These studies do not consider very recent aspects of the ethnic radical parties and movement in the matter of new constitutional formation and hate campaign against the minority Tamil which the present thesis seeks to consider.

\subsection{The LTTE War with State}

Another aspect of state formation and reconstitution is discussed by Stokke (2006a) who studied the capacity of the LTTE, which is captured in the title "Building the Tamil Eelam State: Emerging State Institutions and Forms of Governance in the LTTE-Controlled Areas in Sri Lanka." The article examines this state formation with an emphasis on the functions and forms of governance embedded in the new state institutions. This study is a qualitative inquiry and based on the interviews. During the ethnic civil war, the LTTE began establishing a foundation for a state in areas under its military control. This article provides an account and analysis of the nature and function of the state institutions built by the LTTE and the form of governance it practised. The article also shows the significance of building state institutions of its own to the LTTE's overall project of state formation. The author observes that the emerging state formation in the LTTE-controlled areas had strongly focused on external and internal security, with an additional emphasis on social welfare and economic development. In terms of governance, the LTTE state apparatus was marked by authoritarian centralisation. A few formal mechanisms existed for democratic representation as well as partnership arrangements and institutional experiments that could have fostered other democratic forms of representation and governance. The author concludes that resolving the security problem in tandem with political transformations towards democratic governance remain the prime challenges for peacebuilding in north and east of Sri Lanka.

By contrast, Sarvananthan (2007) writes "In Pursuit of a Mythical State of Tamil Eelam: a rejoinder to Kristan Stokke" to refute the analysis developed by Stokke. The author criticises Stokke's analysis on the following two main grounds: (a) depending solely on LTTE-related sources for information and data, and (b) representing the LTTE as a "liberation movement" with mass support and commitment to performing state functions. This study provides deeper inside in understanding the LTTE's governance and state-like apparatus and its structure. Conversely, the Tamil's strong social force of the LTTE was defeated. Moreover, its state-like or quasi-state structure was totally destroyed in 2009.

Mampillay's (2007) doctoral dissertation "Stationary Bandits: Understanding Rebel Governance," is a wide-ranging scholarly work submitted on an American university. In line with Mampillay's arguments concerning secessionist groups operating in areas formerly penetrated by the state, life in the LTTE territory was impressively stable, with a clear political authority responsible for providing extensive public goods. Literature of rebel groups was utilised to back up the theories explaining the different cases. The study employed quantitative and qualitative methodologies, with Sri Lanka selected as one of the cases in this study. Mampillay focuses on the organisation of the LTTE, the dominant rebel organisation previously operating on the island. With an estimated troop strength of 20,000, the LTTE was arguably one of the best organised non-state military forces ever assembled, with the capacity to fight on land, at sea, and on air. The LTTE-controlled many areas in the north and east of Sri Lanka for extended periods after the outbreak of conflict in 1983. Mampillay explains the unavoidable power-sharing engaged in by the state with the LTTE within the Tiger territory for the government to provide key services to the population under the group's control. Mampillay also argues that, faced with strong state institution's services to which the public had been accustomed to, the LTTE had little choice but to work with the GOSL to establish a joint mechanism that would ensure a continuity of services. Despite the bitter conflict, the GOSL had no choice but to continue its services in coordination with its nemesis the LTTE, that is, if it wanted to maintain ties with the people in the LTTE-controlled territories. Mampillay's study widely focuses on the LTTE's administrative structure, and analyses how they developed the service provision in the north and east. This information are used to provide supportive data and background when preparing the present thesis. 


\subsection{Defeat of the LTTE and Effects}

Nieto's (2009) article "A war of attrition: Sri Lanka and the Tamil Tigers" provides a profound insight into the 26-year secessionist war between the state and the LTTE in which military operations failed to achieve a decisive victory for either side. As a qualitative study, Nieto employs the term "war of attrition" as a conceptual tool to study the civil war and its termination in Sri Lanka. Nieto considers the existing literature and finds Sri Lanka an important case to conduct the study and suggest that the findings of the study are equally useful for regional as well as other countries. His research looks into the historical background of the war and touches on the "hurting stalemate" situation of war at the end of the twentieth-century. He develops his argument by linking the application of Zartman's "ripeness" theory to this "hurting stalemate" situation. The focal point of the study is to analyse the defeat of the LTTE while comparatively explaining international experience (e.g., the US in Vietnam). Nieto stresses the importance of peace through negotiation: "It seems unlikely that either the Sri Lankan military or LTTE can militarily defeat their adversary, meaning that a resolution to the conflict will have to occur through negotiations after an offensive military forces the other side, weakened but not defeated entirely, to agree to the terms placed before it." Nieto's work exhibits some weaknesses, despite the many insights it offers that are supportive of the current study. The paper mostly relays information about the war and its attrition, which failed to allow space for peace. Moreover, Nieto's study fails to consider the ability of the social force to coerce the state into attempting a state reconstitution or attempt secession in context of the post-LTTE climate characterised by a weakened Tamil community and Sinhala hegemonic state, core obstacles to tackling state reconstitution.

Flynn's (2011) “The Liberation Tigers of Tamil Eelam: A Revolution in Military Affairs" is intended to asses guerrilla warfare, and the LTTE is selected for the study. This group is chosen due to their formidable conventional force, which included a maritime arm capable of challenging the Sri Lankan Navy and a nascent air wing capable of striking targets inside the government-held territory. However, even with all the this prowess, the LTTE suffered a crushing military defeat at the hands of the Sri Lankan Armed Forces in May 2009. Flynn's study aims to investigate the factors that caused the downfall of a group believed to be nearly invincible. To achieve this goal, the paper applies a theory of warfare, namely, the revolutions in military affairs (RMAs), as a framework within which to analyse the actions of the LTTE and government of Sri Lanka. Accordingly, the author concludes that the military downfall of the LTTE was a direct consequence of its leader, Velupillai Prabhakaran's fixation with achieving a separate homeland (Tamil Eelam) while ignoring the political implications of changes in the conflict environment. However for his empirical basis to reach this conclusion, the author utilised desk study and secondary sources.

\subsection{The LTTE and International Agenda}

Parasram's (2012) article "Erasing Tamil Eelam: De/Re Territorialisation in the Global War on Terror" and Jirasinghe's (2016) article "The International Community's Intervention during the Conclusion of the War in Sri Lanka" examine the role of national and international factors during the last phase of the war and defeat of the LTTE. These studies view that the international community banning of LTTE on the grounds of it being a terrorist organisation paved the way for the state of Sri Lanka's easy demolition of its enemy. These study supports their arguments by relying on the political situation from the past, to understand the ethnic conflict in Sri Lanka while depending largely on views of the International community. Parasram's (2012) paper considers the possible explanation of the dramatic end to the Sri Lankan civil war through post-colonial territorial politics. Parasram relies on literature in political geography and political science to argue two discourses, namely, post-colonial nationalism and global terrorism, aligned along domestic, regional, and international political levels to enable a military victory of the government. On a domestic political level, a new government was in place, whereas the LTTE found itself in a shocking split with the defection of its Eastern Wing Leader. At the international level, reliance on Western allies was quickly diminishing due to their perceived inability to understand the needs of the Asian front in the Global War on Terrorism. These events led to a warming of relations with China, which was perceived as a nation that understood and was sympathetic to fighting terrorism and secession movements. Through these movements, the domestic civil war was effectively mapped onto the developing regional geopolitics of Southern Asia.

Jirasinghe's (2016) paper discusses the ambivalence in the discourse of the international community over the government's military action, the latter's role in consolidating its hegemony and ultimately its resistance to the efforts made by the International Community in the last stages of the war to find a just solution to the crisis. The study argues that the success of an international community's intervention, to ensure civilian security during a war, depends primarily on the hegemonic alignment between the international community and the state, especially if the state maintains hegemony at the local level. The methodologies used for data collection for this work are the case study and causal process observation (CPO) in a bid to track the engagement between the government and the 
international community over human security during the war and over post-war peace-building period from 2009 to 2015. The sources for analysis relied on transcripts of speeches, press releases, media reports, official documents, and personal interviews. The research draws from the post-colonial theorist Homi K. Bhabha's conceptualisation of ambivalence. For its study, the role of ambivalence in the discourse of the international community as enabling the Sri Lankan state's resistance to the former's authority is reviewed. Most research and writings on Sri Lanka reflect the practical situation at the end of the war and its consequences, with special focus on recent international influence in the Sri Lankan conflict. This thesis obtains sufficient contributions from the scholarly work of these writers to develop Chapters Five and Six, as these studies provide data to look into how the strong social force of the LTTE was eradicated and the strong unitary state was established once again. Both papers are theoretically based, but the first one is not sufficiently clear in terms of methodology, whereas the second paper provides deeper insight into methodology.

\subsection{Post-War State Reconstitution}

In "Sri Lanka: The Challenges of Post-war Peacebuilding, State Building, and Nation Building," Samarasinghe (2009, pp. 436-458) mainly concentrates on one side, the military victory, and its impact on the successful transition to peace and stability through post-conflict reconciliation, peacebuilding, and reconstruction. His study begins with a historical genesis and evolution of the protracted ethnic conflict in Sri Lanka while focusing on causes and origin of the conflict during the colonial and post-colonial periods of Sri Lanka. The beginning of the ethnic conflict, demands of minorities and failure of resolution attempts, several episodes of communal violence, and full-scale war are comprehensively discussed in his account. Further, he discusses end of the war in 2009 and issues that occurred from this point. In his work, he mentions that "Sri Lanka's ethnic war that lasted over 25 years resulted in a militarised country, political fragmentation, deep ethnic division, poor governance and a weak economy. Reconciliation, peacebuilding, and transformation of the politics and economy are essential for Sri Lanka to recover." Moreover, he stresses the challenges posed by soured post-war relations with Western partners of the country due to humanitarian and human rights records of the Sri Lankan government. The excess allocation of the government for defence, strengthening of the military, and undemocratic electoral processes brought about real threats $(2009$, p. 436). In particular, the global arena has been paying attention to mainly the war-affected north and east areas of the country in the post-war scenario. Thus, he concludes that healing the polarisation of ethnic groups, which has developed during a war that lasted one whole generation, is difficult. However, his account is confined to the beginning of the post-war peace-building process in Sri Lanka, although many pages were devoted to the causes and history of the conflict. He emphasises issues and challenges of the post-war situation. This qualitative study largely depends on secondary sources of information. Overall, this paper brings us closer to comprehending the challenges Sri Lanka faces in the process of post-war peace, as well as state, and nation building in the aftermath of the war. His account has been a prime source of information to researchers who envisage learning the historical genesis of ethnic conflict and post-war peacebuilding challenges in the beginning stage of reconciliation. In any case, comprehensive studies are needed to understand the inclusive approach of state reconstitution and transformation in the post-war reconciliation process.

International Crisis Group ([ICG], 2008, pp. 1-28) illustrates in its report that continuous struggles, political insecurity, and the lack of power invested in the newly invested to established provincial council are discouraging and indicate a determined plan for scaring eastern province of the island. The government has yet to devolve power to the eastern province (established in 2008 via election), as required by the 13th Amendment to the constitution, which established the provincial council system in 1987 in response to Tamil demands for regional autonomy in the north and east. This report also demonstrates that the eastern part goes on to face barriers to economic and political advancement. Organisations and international supporters, bearing this conflict in mind, are increasing their efforts to rebuild recently won parts in the Northern Province. Despite the possibility for growth in the eastern part of the country, "it remains far-away from being the model of democratisation and post-war restoration that the government claims." The study recommends that donors should implement a more coordinated set of policies for the war-damaged areas of Sri Lanka, emphasising that "civilian protection, increased continuous supervising of the special effects of aid on conflict dynamics and cooperative encouragement with the government at the top levels." This report provides general phenomena of the recent status of the eastern provincial council and oversight of the international community towards post-war institution building and state reconstitution. The report presents focal points of the democratic governance situation in post-war eastern Sri Lanka.

Nadeeka and Rodney (2010), in their paper "Post-war opportunities for peace in Sri Lanka: An ongoing challenge?" presents two objectives. The first objective is to analyse post-war political climate based on local media reports and personal experiences of the local people. Qualitative pieces of evidence were collected on the ground prior to and immediately following the presidential elections. The second aim is to assess key factors that contributed to 
the war in Sri Lanka by discussing historical interpretations and post-colonial political reform. The article suggests an outline for a sustainable path to peace with the inclusion of all Sri Lankans as co-owners of an inclusive peace process, where concrete steps are taken towards reconstruction, reconciliation, and promotion of democratic principles, as well as participatory strategies in political development and change. The Sri Lankan conflict is widely attributed to the ethnic rivalry between majority Sinhalese and minority Tamils in the post-independence era. The Tamil demand for state reconstitution and state's discriminatory policies were root causes for the conflict. However, these authors focus on including all communities in the country for a lasting solution to the conflict, which is a noteworthy recommendation. By contrast, these suggestions, if implemented could harm the Tamils who were the major victims of the conflict. Hence, this thesis is carried out with the aim of filling that scholarly lacuna with regards to Sri Lankan Tamils.

The essay by De Votta (2011) "From civil war to soft authoritarianism: Sri Lanka in comparative perspective," suggests that the best description of Sri Lankan politics under the Rajapaksa regime is "soft authoritarianism." The argument is that soft authoritarian dispensation was directly linked to Sinhalese Buddhist ethnocentrism and the battle against the LTTE and could represent the most destructive legacy of the country's civil war. Part of the theoretical literature makes very good sense and captures the idea of soft authoritarianism from existing literature. The essay provides deep insight into empirical cases from around the world, in comparison to the Sri Lankan experience. De Votta elaborates on soft authoritarianism in Sri Lanka: "it is thus within the realm of possibility that Sri Lanka's current soft authoritarianism can also morph into a dictatorship should President Mahinda Rajapaksa and his family, utilising the military, decide to stay entrenched in power by hook or by crook." He backs his argument on the existence of soft authoritarianism in Sri Lanka through the systems that were placed by the Rajapaksa regime, which included muzzling of the media, undermining political opponents, the upper hand in the military and over his defence secretary, and nationalist ideology. De Votta accurately explains the recent past situation in the country, but he does not consider the economic growth of the state from lower to middle-income status similar to other soft authoritarian states. De Votta's study gives support to construct the arguments in the present thesis.

The paper by Hoglund and Orjuelas (2011) on "Winning the Peace: Conflict prevention after the victor's peace in Sri Lanka" focuses on conflict prevention in post-war Sri Lanka, and mainly explores the limitations of international discourses and practices. The study is scholarly, interesting, innovative, and contributes to the literature on the post-war peacebuilding process of Sri Lanka with the application of conflict prevention theory. The main sources for the paper are collections of secondary data, such as scholarly works and reports. One of the points the researcher of this thesis found most appealing is the way in which the authors presented how growing Asian super powers, such as China, are working with a different approach to influence the policies of the Sri Lankan government towards conflict prevention measures, but Western alliances lack influence or interest. The strength of this paper is the fresh initiative to analyse post-war Sri Lanka, and its significance of in understanding how the victory of one side could prevent conflict.

This evaluation is a lesson based on Sri Lanka as well as other war-torn countries in the world where intra-state conflict is at peak. In many places, the paper reads with the strength of evidence, whereby authors tell readers about the progress and challenges of all four dominant factors (demilitarisation/militarisation, political power-sharing and reform, justice and reconciliation, and post-war reconstruction and economic development). In addition, the authors' way of presenting research findings by other scholars makes for more interesting and informative insight of the contemporary situation in Sri Lanka. The authors give slight emphasis to political or structural reform, with the support of conflict prevention theory. They stress the series of missed opportunities by Sri Lanka with regards to political reform. "The President has consolidated political power in a series of provincial elections as well as in the presidential and parliamentary elections in January and April 2010." The authors highlight that this consolidation of power could have been used to implement reforms of the state structure in favour of devolution of power and decentralisation of the state, which have been on the political agenda as a solution to the conflict for decades (Uyangoda, 2010 as cited in Hoglund \& Orujuela 2011, p. 28)

Darini (2010) emphasises the same idea in her study, where she claims that "the identity conflict that preceded it may persist in different forms until issues of power-sharing with the regions due to over-centralisation of State institutions, and erosion of democratic governance are addressed." She discusses the essential need for devolution of power in the Northern and Eastern Provinces where Tamils and Muslims predominantly live. Darini does not broadly explain how centralised power needs to be devolved, apart from recommending accountability, transference, and inclusiveness of the institutional set up to find the sustainable political solution in post-war Sri Lanka. 
In his recent work "Political Trend in Post-war Sri Lanka," Sahadevan (2010) examines the issues of whether after the defeat of the secessionist war, Sri Lanka can move towards a post-war society with an agenda of ethnic reconciliation and political reconstitution that will reflect the plurality of countrie's society as well as address the concerns of ethnic minority groups on the question of minority political rights. The author argues that the triumphalist regime led by President Mahinda Rajapaksa, which was the same war that spearheaded the military victory over the LTTE, was incapable of making such a transformation. This is due to various reasons. For instance, the regime itself was oriented towards Sinhala Buddhist nationalism at an ideological level and did not recognise the legitimacy of the political rights of ethnic minorities. The ruling regime had instead emphasize its commitment to maintaining and safeguarding the unitary state from any threat, be it secessionism or federalism, and a commitment to further centralisation of state power through political reform.

How can contestation be conducted among ethnic competitors in post-war Sri Lanka? The answer to this question can be found in another study by Sahadevan, "Unitarism, Separatism and Federalism: Competing Goals and Problems of Compromise in Sri Lanka" (2012), which explores how competing goals among ethnic contestants in Sri Lanka had compromised regional autonomy. The study shows how the extreme positions and uncompromising attitudes of the unitarianists and separatists paved the way for federalists as a potential force for moderation and compromise. However, the author further shows how unitarianists and separatists - the "ethnic enemies"-in turn found federalists as their "common adversary," and how they, while seeking to annihilate each other, also jointly sought to destroy the federalists. The main assumption on which the analysis is based on the following: the ideological entrenchment in unitarianism or separatism is a deeply ethnicized, thus the resistance to any political compromise. The chapter begins with the characteristic description of Sri Lanka's polity and society and then provides an account of the position advanced by the unitarianists, separatists, and federalists. The last section reviews how the unitarianist project became strengthened in the post-war context. Nonetheless, Sahadevan does not give attention to recent political developments, including post-war constitutional formation and the fresh demand of Tamils for federalism, issues that the present thesis analyzes.

Goodhand's (2012) "Sri Lanka in 2011: Consolidation and Militarization of the Post-War Regime" cuts across the entire fabric of post-war development and devolution. He makes note of the slow progress towards a political solution in contrast to infrastructure development projects that are fast paced. He notes the lack of significant steps taken to secure a political settlement and reconciliation with the Tamil community since the end of the civil war (Goodhand, 2012, pp. 130-137). The paper highlights the centralization of state power, regime consolidation, presidential control over state power, and his family dynasty. The paper considers post-war economic development in the country whose growth was very fast and attracts adequate international attention to receive loans from the IMF. Infrastructure developments in the northern and eastern provinces have been accounted for in his study. In addition, this paper focuses on recent local government, provincial council, and general and presidential elections, as well as reviews the results of these elections. Moreover, the paper briefly discusses international allegations of war crimes and accountability issues during the last phase of the war, especially focusing on the initiatives of the (UN) secretary general and the response of Sri Lanka in the form of the LLRC. This paper contributes to the last part of this thesis, which is an analysis of recent political developments in the state. The very brief post-war account of the multiple sector process in Sri Lanka needs more comprehensive focus, and state reconstitution and centralization of state power are briefly discussed.

The prominent political science scholar in Sri Lanka, Uyangoda (2000 a\&b, 2005, 2009, 2010a, 2011a\&b, 2012 \& $2013 \mathrm{a} \& b)$ reviews the political reform debate in Sri Lanka in his various research works. In "State of Desire? Some Reflections on the Unreformability of Sri Lanka's Post-Colonial Polity," Uyangoda (2000a) critically evaluates the possibilities of reforming the state in the context of escalating civil war. Written against the backdrop of Sri Lanka's 50 years of political independence from colonial rule, the author argues that despite the Tamil minority's mobilization to reform the existing unitary state, the state has been resistant to reform. In explaining this thesis, the author examines the changing class nature of political power, the role of ideology in social mobilization for state power, and the counter reformist thrust of counter-state politics. The shift of political power, from the traditional Sinhalese elite of the capitalist class to the intermediate classes of Sinhalese society, was a development that occurred in the mid-1950s. Consequently, this shift has made state reform to meet minority demands doubly difficult. Uyangoda (2005), in another of his academic work, argues that "Sri Lanka's unitary state and consequently much of its pluralist contestations are products of a precise colonial legacy, particularly the organization and reproduction of the constitutional principle of European/British unitary state in the island. Only after decades of violent ethnic conflicts between the minority Tamils and the majoritarian Sinhalese population did the Sinhalese ruling elite realize the need for altering the unitarist bases of the Sri Lankan state within a framework of ethnicity-based power sharing." 
Uyangoda (2010b, pp. 29-78) later states that "when the civil war ended, Sri Lanka did not seem to be moving in the direction of political reform for the foreseeable future." His paper is organised into three analytical sections. The first section elaborates how the broadening of the social bases of political power has paradoxically led to the narrowing down of the ethnic foundation of Sri Lanka's post-colonial state with direct consequences for what can be and what cannot be achieved in a program of state reform. The second section of the paper identifies and comments on the constraints on reform embedded in institutionalised spaces of political power. In the final section, the discussion leads to non-institutional, but social spaces and practices that give meaning to contests for power in Sri Lankan society. The paper ends with a postscript that highlights the paradox of political reform difficulty in Sri Lanka even after the end of the civil war, which earlier stood as a barrier to reform.

In another study, Uyangoda (2011b, pp. 35-61) identifies difficulties and failures in state reform attempts in the post-independent Sri Lanka, and how the absence of the reforms affect the future of Sri Lanka. Moreover, he employs "the concept of 'ethnocracy' as a theoretical tool to understand the problematic absence of state reform amidst a secessionist civil war in Sri Lanka." The paper provides an interesting analytical description of the necessity and political impossibility of the reforms in recent decades. He describes that the argument for state reform during the civil war is based on the premise that state reform can be a means to ending the ethnic conflict and secessionist war. Significantly, this paper focuses on the Sinhalese ruling class and its capacity of using the divide-and-rule strategy on Tamil and Muslim minorities. Thus, "the internally divided minorities have weakened their political bargaining capacities, except for sharing spoils of power."

Uyangoda's (2012) account in "Introduction: Reframing Democracy-Perspective on the Cultures of Inclusion and Exclusion in Contemporary Sri Lanka" studies Sri Lankan political history since the mid-1950s, a period replete with failed attempts at state reform. He briefly takes the chronological failure of state reform attempts among elites of the Sinhalese majority and Tamil minority for interpretation. In another of his recent accounts, in the same volume, "Local Democracy and Citizenship in the Social Margins," he presents the argument that the existing form and practices of local democracy do not weaken the social and cultural structures that produce marginality in social as well as political spaces. Therefore, the existing local democracy has become a socially conservative form of democracy that has lost its capacity for egalitarian social transformation in rural society. An argument for state reform begins with a critical understanding of the conditions, forms, and practices of unequal local democracy that continues to reproduce social marginality. The study was based on a qualitative material gathered from the Kurunegala District, North Western province, on a marginalised case community in Sinhalese society. The central argument presented has three components: (1) Sri Lanka's democratisation process, in general, has reached a crisis, (2) deficits in a democracy that are visible in rural society are consequences of "arrested democracy," and (3) the expansion of local democracy requires social transformation at the local level.

The introduction of the edited volume of "State Reform in Sri Lanka: Issues, Directions and Perspectives" (2013b) presents the key issue concisely in post-colonial Sri Lankan politics in the mode of a question: "Should the post-colonial state be re-structured and reformed and its basic institutional architecture re-designed?" Uyangoda continues to explain the state structure in post-independence Ceylon from a historical views of the 1930s period. He stresses the ethnic perspective that links with "the main ethno-nationalist project." He mentions the two attempts of state reform of Sri Lanka in 1972 and 1978 that failed as a result of different perspectives and agenda of ruling political parties.

Chapter 2 of "Sri Lanka's State Reform Debate-Unitarism, Federalism, Decentralisation, and Devolution" by Uyangoda maps out the political and thematic composition of the discourse of state reform after independence. The chapter shows that initially, the debate unfolded on two conceptual binaries concerning the structural organisation of post-colonial Sri Lankan state, which was, first, unitarism versus federalism, and second, decentralisation versus devolution. These two binaries provided the foundation framing for the state reform debate. The chapter outlines this conceptual debate to show (a) how the state reform debate has been shaped by different turns and contexts of the ethnic conflict, (b) ways in which the ethnic conflict and state reform perspective influence each other, and (c) complex politics that shaped the trajectories of the state reform process itself. As the chapter shows, the debate becomes intense, such as when the ethnic conflict became a civil war and gave rise to new thematic controversies. The key controversies were centred on the following themes: Is devolution federalism by another name? Does it, or does it not, affect the unitary character of the state? (b) Is devolution adequate to offer as an alternative to secession? (c) What is the acceptable extent to which devolution can reasonably be allowed and what is the nature and scope of the territorial unit of devolution? (d) What would the small minorities get in a regime of devolution? When the war ended in 2009, the state reform debate become reconstituted, which raised a new question about state reform: Is devolution relevant in the post-war context when the separatist threat to the 
state is no longer a factor in the island's politics? As the chapter shows, the intensity of these debates even defined but restricted the political space for carrying out any significant state reform agenda towards more devolution.

In the very last chapter of this volume, Marcelline and Uyangoda (2013) engage in the most interesting debate. The process of the status of state reform agenda in the aftermath of the defeat of the LTTE is presented in their account of "Post-Civil War in Sri Lanka: The Dilemmas of State Reform." They assert that one of the strongest arguments against state reform in any manner during the civil war was the presence of the LTTE as a threat to the state. Granting more powers of autonomy to the north and east, while LTTE's secessionist threat prevailed, was seen as a politically imprudent and strategically suicidal policy option. Hence,

It was in this context that many observers viewed the LTTE's defeat in May 2009 as a decisive turning point in the history of the island's ethnic conflict. The absence of the threat of secession, it was felt, would provide the space for the political elites of all ethnic communities to address the question of group rights of the ethnic minorities and move forward on an agenda of state reform that would democratise the social and ethnic bases of the Sri Lankan state (p. 294). According to the authors, all efforts for political solution to the ethnic conflict failed as a result of unwillingness of both conflicting elites of Sinhalese and Tamils. The Rajapaksa government strengthened its power via a two-thirds parliamentary majority. The regime centralized state power and the President controlled state power through 18th Amendment.

Uyangoda and his co-authored studies are high-impact scholarly qualitative studies and comprehensively support the present thesis with guidelines and background of both the state and society during the reconstitution process. Given that the prime focus of his interpretation is of state reform during the post-independence period, during the war and in the post-war situation, he applies theories about ethnocracy, democracy, and peace-building in his studies, but he does not consider the latest state-in-society theory of Migdal. Similarly, in "War Making and State Building: The Politics of State Reform in Sri Lanka," Marcelline (2014) studies past initiatives at state reform and identifies the impediments that caused the failure of such attempts from post-1983 up to present. The study employs the approach to look at state reform from the experiences and perspective of the political elites. The findings of the book reflect the behavior of the political elite vis-à-vis the question of state reform.

The findings of the above book are based on an archival survey of newspaper reportage on past attempts at state reform, election literature, and interviews with political leaders. The book engages in the condition for state reform in post-war Sri Lanka. Section One of the book indicates all efforts for state reform in chronological order and its continuous failure since 1983. Section Two is more insightful of the main argument of the inability of political elites to institute state reformation. The next section reveals constraints in the two decades of efforts for power sharing. The crucial finding of the section shows that "the LTTE captured and controlled a portion of territory with a willingness to enter into a political engagement with the Sri Lankan ruling elite which stemmed from a desire to gain official recognition for the LTTE's de-facto state status" (p.47). The final section of the study provides more insights of post-war state reform in Sri Lanka with more details of recent events and difficulties to find political solution/state reform. This section considers modes of activity of economic, peace-building approach, and centralization process in the previous regime. However, Marcelline does not deal with contemporary developments of the initiatives to form a new constitutional solution.

The new research that compiled the constitutional reform process of Sri Lanka is the work by Welikala (2015a). "Sri Lanka's Long Constitutional Moment" brings the debate over constitutional reform into focus and leads to a number of important initiatives by the new government headed by President Maithripala Sirisena. The qualitative inquiry looks into the contemporary constitutional reform debate in Sri Lankan politics. This paper discusses the Nineteenth Amendment that promised constitutional reforms to the Constitution between the presidential and parliamentary elections, and the program of further reforms that the new government has promised. The Nineteenth Amendment was the centrepiece of a "100-day program" of constitutional and governance reforms offered by the current government at the presidential election, which, in addition to the reforms to the presidency, included other measures, such as a Freedom of Information Act and a reform of the parliamentary committee system. At the moment, other measures have yet to be fulfilled as more attention was paid to enacting the Nineteenth Amendment, in the face of the obstructionist tactics of the opposition parliamentary majority. The amendment was a welcome start, even though the proposal did not go as far as was expected. The enactment is hopefully a start to a series of much needed constitutional reforms to consolidate democracy and devolution in Sri Lanka. Whether the democratic reawakening indicated by the two elections of 2015 will be a success depends on both the president and Prime Minister working together to complete the process. The elections have created an opportunity for constitutional reforms to take a more sensible approach in contrast to the past administrations. The maximum use of the opportunity is important for the nation to take full advantage of its economic, social, and political potential. This paper covers the recent state reform and constitutional making agenda of the present 
government, and mainly focuses on the 19th Amendment to the constitution and its challenges. The study, however, has not taken into account the recent initiative of new constitutional formation process and its present and future challenges, which must stress inclusiveness of minority into the state system.

\section{Conclusion}

The foregoing literature survey indicates that there are many theoretical and empirical gaps to be studied with respect to state-minority contestation in post-colonial Sri Lanka. The first relates to the state-in-society theory, by which Migdal emphasizes the importance of expanding and developing an approach through a review of the role of the state-in-society. He looks into the elements of state and society that need to transform and constitute one another, but does not devote attention to how the majority and minority parties are included and excluded when the state is constituted within a multi-ethnic setup. In addition, the state-in-society approach focuses on formal and informal social forces that engage with the state on behalf of society.

Different forms of forces, especially how militant social forces form and how they deal with the state in the best interests of the segment of society they represent, were not studied. Moreover, the plural or multi-ethnic society has great potential to lead to state-minority contestations and civil wars. If a civil war is brought to a close through the influence of national and international forces, then the result would be a military victory for one side but there would be a very resentful population of losers on the other side. The weakening of one side through defeat and the triumphalism of the winning side could never lead to a lasting peace.

The literature review indicated that previous empirical studies made by the state of Sri Lanka mainly considered identity formation, state reform through decentralization, and devolution to find a solution to the ethnic conflict. After the war ended, the government also embarked on post-war peace-building, reconstruction, and economic liberalization. There was little in the literature about how the state and society intended to share power from a state-in-society perspective in the Sri Lankan context, particularly after the July 1983 pogrom against the Tamils.

The existing empirical studies fail to review how the state destroyed militant social forces and overcame them in the period following the national and international political developments that took place after the September 11, 2001 attack on the WTC in New York in the US. This survey indicates a paucity of literature that examines the state's reluctance to introduce inclusive policies after the war. Further, it reveals that previous studies were based on secondary sources and were sometimes biased. It is clear that priority should be given to conducting more field surveys to fill the existing gaps.

\section{Acknowledgements}

The author is grateful to the Higher Education for Twenty-first Century (HETC) Project (No. SEUSL/A\&C/N2) and to National Centre for Advanced Studies in Humanities \& Social Sciences (NCAS) (No. 13/NCAS/SEUSL/SocSc/26) for the financial support for this study.

\section{References}

Alavi, H. (1972). The state in post-colonial societies: Pakistan and Bangladesh. New Left Review, 1(74), 59-81.

Almond,G. A., \& Verba, S. (1963). The civic culture: Political Attitudes and Democracy in Five Nations. Princeton, New Jersey: Princeton University Press. https://doi.org/10.1515/9781400874569

Amin-Kahan. (2012). The post-colonial state in the era of capitalist globalization: Historical, Political and Theoretical Approaches to State Formation. New York, USA: Routledge. https://doi.org/10.4324/9780203127308

Archer, A. M. S. (1985). The myth of cultural unity. British Journal of Sociology, 36, 33-53. https://doi.org/10.2307/590456

Bastian, S. (2009). The politics of land reform and land settlement in Sri Lanka. Articles. Retrieved from http:/www.sunilbastian.com/content_images/1401161701Politics\%20of\%20Land\%20Reform\%20in\%20Sr i\%20Lanka.pdf

Bastian, S. (2011). Politics of market reforms and the UNF-led negotiations. In J. Goodhand, J. Spencer, \& B. Korf (Eds.), Conflict and Peace-building in Sri Lanka: Caught in the Peace Tramp? London, UK: Routledge.

Bastian, S. (2013). Post-colonial Sri Lankan state, the rural Sinhalese society and the ethno-political conflict. In Uyangoda (Ed.), State reform in Sri Lanka: Issues, Directions and Perspectives. Colombo, Sri Lanka: Social Scientists' Association.

Bates, R. H. (1981). Markets and states in tropical Africa: The Political Basis of Agricultural Policies. Berkeley, USA: University of California Press. 
Bates, R. H. (1989). Beyond the miracle of the market: The Political Economy of Agrarian Development in Kenya. New York, USA: Cambridge University Press.

Berger, A. A. (2000). Media and communication research methods: An Introduction to Qualitative and Quantitative Approaches. Thousand Oaks, USA: SAGE Publications.

Bose, S. (2004). Decolonisation and state building in South Asia. Journal of International Affairs, 58(1), 95-113.

Bose, S., \& Jalal, A. (2004). South Asia, history, culture, political economy (2nd ed.). New York: Routledge. https://doi.org/10.4324/9780203712535

Brown, J. S., Collins, A., \& Duguid, P. (1989). Situated cognition and the culture of learning. Educational Researcher, 18(1), 32-42. https://doi.org/10.3102/0013189X018001032

Coomaraswamy, R. (1993a). The select committee process and the failure of politics. The Thatched Patio, Special Issue, Sri Lanka: Provincial Council Elections and Devolution, 6(5).

Coomaraswamy, R. (1993b). Constitution and constitutional reform. In K.M. De Silva (Ed.), Sri Lanka: Problems of Governance. Kandy, Sri Lanka: International Centre for Ethnic Studies.

Coomaraswamy, R. (1996). Ideology and the constitution: Essays on Constitutional Jurisprudence. Colombo, Sri Lanka: International Centre for Ethnic Studies.

Darini, R. S. (1999). Democracy and problem of representation: The making of Bi-polar ethnic identity. In J. Pfaff-Czarnecka, R. S. Darini, A. Nandy, \& E. T. Gomez (Eds.), Ethnic futures: The State and Identity Politics in Asia. New Delhi, India: Sage.

De Votta, N. (2000). Control democracy, institutional decay, and the quest for Eelam: Explaining Ethnic Conflict in Sri Lanka. Pacific Affairs, 73(1), 55-76. https://doi.org/10.2307/2672284

De Votta, N. (2004). Blowback: Linguistic Nationalism, Institutional Decay, and Ethnic conflict in Sri Lanka. Stanford, CA: Stanford University Press.

De Votta, N. (2011). Sri Lanka from turmoil to dynasty. Journal of Democracy, 22(2), 130-144. https://doi.org/10.1353/jod.2011.0019

Dooley, D. (2001). Social research methods (4th ed.). Upper Saddle River, NJ : Prentice Hall.

Evans, P., Reuschmeyer, D., \& Skocpol, T. (Eds.). (1985). Bringing the state back In. Cambridge: Cambridge University Press. https://doi.org/10.1017/CBO9780511628283

Flynn, K. (2011). The liberation tigers of Tamil Ealam: A Revolution in Military Affairs. (Unpublished Master's Thesis) The Faculty of the Graduate School of Arts and Sciences of Georgetown University.

Geertz, C. (1973). The Interpretation of cutlers: Selected Essay. New York, USA: Basic Book.

Goodhand, J. (2012, January/February). Sri Lanka in 2011 consolidation and militarization of the post-war regime. Asian Survey, 52(1), 130-137. https://doi.org/10.1525/as.2012.52.1.130

Gramsci, A. (1971). Selections from the prison notebooks. In Q. Hoare, \& G. N. Smith (Eds.). New York, USA: International Publishers.

Haddad, M. A. (2010). The state-in-society approach to democratization with examples from Japan. Division II Faculty Publications. Paper 169. Retrieved from http://wesscholar.wesleyan.edu/div2facpubs/169

Herbst, J. (2000). States and power in Africa: Comparative Lessons in Authority and Control. Princeton, USA: Princeton University Press.

Hoglund, K., \& Orjuela. C. (2011). Winning the peace: Conflict Prevention after a Victor's Peace in Sri Lanka. Contemporary Social Science, 6(1), 19-37. https://doi.org/10.1080/17450144.2010.534491

Horowitz, D. L. (1989). Insentives and bahaviour in the ethnic politics of Sri Lanka and Malaysia. Third World Quarterly, 11(4), 18-35. https://doi.org/10.1080/01436598908420189

International Crisis Group [ICG]. (2008). Sri Lanka's Eastern Province: Land, Development, Conflict. Asia Report No. 159.

Jeganathan, P., \& Ismail, Q. (1995). UN-making the nation. Colombo, Sri Lanka: Social Scientists' Association.

Jirasinghe, R. C. (2016). The international community's intervention during the conclusion of the war in Sri Lanka. Strategic Analysis, 40, 291-306. https://doi.org/10.1080/09700161.2016.1184789 
Kearney, R. N. (1967). Communalism and language in the politics of Ceylon. Durham, USA: Duke University Press.

Kohli, A., \& Shue, V. (1994). State power and social forces: On Political Contention and Accommodation in the Third World. In S. Migdal, A. Kohli., \& V. Shue (Eds.), State power and social forces: Domination and Transformation in the Third World. Cambridge, United Kingdom: Cambridge University Press.

Krasner, S. D. (1984, January). Approaches to the state: Alternative Conceptions and Historical Dynamics. Comparative Politics, 16(2), 223-52. https://doi.org/10.2307/421608

Laitin, D. D. (1986). Hegemony and culture: Politics and Religious Change among the Yoruba. Chicago, USA: University of Chicago Press.

Leitan, G. R. T. (1990). Political integration through decentralization and devolution of power: The Sri Lankan Experience. Colombo, Sri Lanka: Department of History and Political Science, University of Colombo.

Loganathan, K. (1996). Sri Lanka, lost opportunities: Past Attempts at Resolving Ethnic Conflict. Colombo: University of Colombo.

Ludden, D. (Ed.). (2001). Reading subaltern studies: Critical Histories, Contested Meanings, and the Globalisation of South Asia. New Delhi, India: Permanent Black Publishers/London, UK: Anthem Press.

Mampilly, Z. C. (2007). Stationary bandits: Understanding Rebel Governance (University of California), (Doctoral Dissertation). Retrieved from http://pages.vassar.edu/mampilly/files/2013/11/Mampilly-Dissertation-Final.pdf

Marceline, S., \& Uyangoda, J. (2013). Post-civil Sri Lanka: Dilemmas of State Reform. In J. Uyangoda (Ed.), State Reform in Sri Lanka: Issues, Directions and Perspectives. Colombo, Sri Lanka: Social Scientists' Association.

Marcelline, S. (2014). War making and state building: The Politics of State Reform in Sri Lanka. Colombo, Sri Lanka: International Centre of Ethnic Studies.

Migdal, J. S. (2001a). State in society: Studying how States and Societies Transform and Constitute One Another. New York, USA: Cambridge University Press. https://doi.org/10.1017/CBO9780511613067

Migdal, J. S. (2001b). Through the lens of Israel: Explorations in State and Society. Albany, USA: State University of New York Press.

Migdal, J. S. (2004). Mental maps and virtual checkpoints: Struggles to Construct and Maintain State and Social Boundaries. In J. S. Migdal (Ed.), Boundaries and belonging: States and Societies in the Struggle to Shape Identities and Local Practices. New York, USA: Cambridge University Press. https://doi.org/10.1017/CBO9780511510304.002

Migdal, J. S. (1994). State power and social forces: Domination and Transformation in the third world. Cambridge, UK: Cambridge University Press. https://doi.org/10.1017/CBO9781139174268

Moore, M. (1990). Economic liberalization versus political pluralism in Sri Lanka. Modern Asian Studies, 24(2), 593-642. https://doi.org/10.1017/S0026749X00010350

Moore, M. (1992, March). Retreat from democracy in Sri Lanka. The Journal of Commonwealth \& Comparative Politics, 17(1). https://doi.org/10.1080/14662049208447625

Nadeeka, A., \& Rodney, A. (2010). Post-war opportunities for peace in Sri Lanka: An Ongoing Challenge? Global Change, Peace \& Security, 22(3).

Nieto, W. A. S. (2008). A war of attrition: Sri Lanka and the Tamil Tigers. Small Wars \& Insurgencies, 19(4), 573-587. https://doi.org/10.1080/09592310802462398

Nordinger, E. A. (1981). On the autonomy of the democratic state. Cambridge, MA: Harward University Press.

Nugent, D. (1993). Property relations, production relations, and inequality: Anthropology, Political Economy, and the Blackfeet. Journal of American Ethnological Society, 20(2), 336-362. https://doi.org/10.1525/ae.1993.20.2.02a00070

Nugent, D. (1994). Building the state, making the nation: The Bases and Limits of State Centralization in "Modern" Peru. American Anthropologist, 96(2), 333-369. https://doi.org/10.1525/aa.1994.96.2.02a00040

Pade, B. (2010). Ethnic conflict and state formation in post-colonial Africa: A Comparative Study of Ethnic Genocide in the Congo, Liberia, Nigeria, and Rwanda-Burundi. Journal of Third World Studies, 27(2), 149. 
Parasram, A. (2012). Erasing Tamil Eelam: De/Re Territorialisation in the Global War on Terror. Geopolitics, 17(4), 903-925. https://doi.org/10.1080/14650045.2012.654531

Robert, M. (2001a). Primordialist stands in contemporary Sinhala nationalism in Sri Lanka: Urumaya as Ur. In A history of ethnic conflict in Sri Lanka, recollection, reinterpretation, and reconciliation, Marga Monograph Series on Ethnic Reconciliation, No 20, Colombo: Marga Institute.

Robert, M. (2001b). Burden of history: Obstacles to Power Sharing in Sri Lanka. In A history of ethnic conflict in Sri Lanka, recollection, reinterpretation, and reconciliation, Marga Monograph Series on Ethnic Reconciliation, No 21, Colombo: Marga Institute. https://doi.org/10.1177/006996670103500104

Sahadevan, P. (2012). Unitarianism, separatism and federalism: Competing Goals and Problems of Compromise in Sri Lanka. In M. A. Miller (Ed.), Autonomy and armed separatism in South and South East Asia. Singapore: Institute of South East Asian Studies. https://doi.org/10.1355/9789814379984-011

Samarasinghe, S. W. R. de. A. (2009). Sri Lanka: The Challenges of Post-war Peace Building: State Building and Nation Building. Nationalism and Ethnic Politics, 15(3), 1557-2986. https://doi.org/10.1080/13537110903393462

Sarvananthan, M. (2007). In pursuit of a mythical state of Tamil Ealam: A Rejoinder to Kiristian Stokke. Third World Quarterly, 28(6), 1185-1195. https://doi.org/10.1080/01436590701507628

Shyamika, J. S. (2013). In pursuit of hegemony: Politics and State Building in Sri Lanka. (Dissertation of Research Programme of Ceres, Research School for Resource Studies for Development, International Institute of Social Studies, The Netherland).

Skocpol, T. (1979). State and social revolutions: A Comparative Analysis of France, Russia and China. New York, Cambridge: Cambridge University Press. https://doi.org/10.1017/CBO9780511815805

Stokke, K. (2006). Building the Tamil Eelam state: Emerging State Institutions and Forms of Governance in LTTE-Controlled Areas in Sri Lanka. Third World Quarterly, 27(6), 1021-1040. https://doi.org/10.1080/01436590600850434

Stokke, K., \& Uyangoda, J. (2011). Liberal peace in question: Politics of State and Market Reform in Sri Lanka. London, UK \& New York, USA: Anthem Press.

Thambiah, S. J. (1986). Sri Lanka: Ethnic Fratricide and the Dismantling of Democracy. Chicago, USA: The University of Chicago press.

Tiruchelvam, N. (2000). The politics of federalism and diversity in Sri Lanka. In Y. Ghai (Ed.), Autonomy and ethnicity: Negotiating Competing Claims in Multi-ethnic states. Cambridge, UK: Cambridge University Press. https://doi.org/10.1017/CBO9780511560088.009

Uyangoda, J. (2000). A state of desire? Reflections on the unreformability of Sri Lanka's post-colonial polity. In S. T. Hettige, \& M. Mayer (Eds.), Sri Lanka at the crossroads: Dilemma and Prospects after 50 Years of Independence. New Delhi, India: MacMillan India Ltd.

Uyangoda, J. (2005). Ethnic conflict, ethnic imagination and democratic alternatives for Sri Lanka. Futures, 37(9), 959-988. https://doi.org/10.1016/j.futures.2005.01.018

Uyangoda, J. (2009, February). Sri Lanka sans the LTTE? Economic and Political Weekly, 44(7), 8-9.

Uyangoda, J. (2010a). Sri Lanka after the presidential election. Economic and Political Weekly, 45(6), 12-13.

Uyangoda, J. (2010b). Sri Lanka: Recent shifts in Minority Rights Debate. In M. Manchanda (Ed.), States in conflict with other minorities: Challenges to Minority Rights in South Asia. Los Angeles, London \& New Delhi: SAGE Publications.

Uyangoda, J. (2011). Redesigning architecture of the state? Sri Lanka's Transition from Civil war to Post-Civil War State. In E. Sridaran (Ed.), International relations theory in South Asia, Volume I Security, Political Economy, Domestic Politics, Identities, and Images. New Delhi, India: Oxford University Press.

Uyangoda, J. (2011). Travails of state reform in the context of protracted civil war in Sri Lanka. In K. Stokke, \& J. Uyangoda (Eds.), Liberal Peace in Question (pp. 35-61). London \& New York: Anthem Press.

Uyangoda, J. (2012). The state in post-colonial Sri Lanka: Trajectories of Change. In D. Kjosavix, \& P. Vedeld (Eds.), The political economy of environment and development in a globalised world: Exploring the Frontiers (pp. 345-73). Essays in honour of Nadarajah Shanmugaratnam. Colombo, Sri Lanka: Social Scientists' Association. 
Uyangoda, J. (2013a). The puzzle of state reform during the civil war: Context, Barriers and outcomes. In Uyangoda (Ed.), State reform in Sri Lanka: Issues, Directions and Perspectives. Colombo, Sri Lanka: Social Scientists' Association.

Uyangoda, J. (2013b). Sri Lanka state reform debate-Unitarism, Federalism, Decentralization and Devolution In Uyangoda (Ed.), State reform in Sri Lanka: Issues, Directions and Perspectives. Colombo, Sri Lanka: Social Scientists' Association.

Webber, M. (1964). Theory of social and economic organization. New York, USA: Free Press.

Weiner, M. (1987). Competitive election in developing countries. Durham, USA: Duke University Press.

Welikala, A. (2015). Sri Lanka's Long Constitutional Moment. The Round Table. The Commonwealth Journal of International Affairs, 104(5), 551-562. https://doi.org/10.1080/00358533.2015.1090799

Young, C. (1994). The African colonial state in comparative perspective. New Haven, USA: Yale University Press.

Young, C. (2013). The postcolonial state in Africa: Fifty Years of Independence. Madison, USA: University of Wisconsin Press.

\section{Copyrights}

Copyright for this article is retained by the author(s), with first publication rights granted to the journal.

This is an open-access article distributed under the terms and conditions of the Creative Commons Attribution license (http://creativecommons.org/licenses/by/4.0/). 